\title{
Assessment of Undiscovered Continuous Tight-Gas Resources in the Mesaverde Group and Wasatch Formation, Uinta-Piceance Province, Utah and Colorado, 2018
}

$U_{\text {sing a geology-based assessment methodology, the U.S. Geological Survey estimated undiscovered, technically recoverable mean }}$ resources of 24 trillion cubic feet of gas in the Mesaverde Group and Wasatch Formation of the Uinta-Piceance Province in northeast Utah and northwest Colorado.

\section{Introduction}

The U.S. Geological Survey (USGS) completed a geology-based assessment of continuous (unconventional) tight-gas resources of the Upper Cretaceous Mesaverde Group and Paleogene Wasatch Formation in the Uinta and Piceance Basins of northeast Utah and northwest Colorado (fig. 1). The Mesaverde Total Petroleum System (TPS) produces mostly natural gas from basin-centered accumulations in the two basins. The main sources are primarily coal and carbonaceous shale and siltstone in the Mesaverde Group. This assessment is based on the TPS concept and related geologic criteria and includes information on the hydrocarbon source rocks, reservoir rocks, and hydrocarbon traps. In this study, we defined the Mesaverde TPS and two continuous assessment units (AUs) that have similar structural, stratigraphic, and petroleum-charge histories. The assessment input data for each AU are shown in table 1.

\section{Total Petroleum System}

The Mesaverde TPS extends across the Uinta and Piceance Basins of northeast Utah and northwest Colorado (fig. 1) and consists of a mix of lithologies (sandstone, mudstone, and coal) associated with fluvial, flood plain, coastal plain, and nearshore marine depositional settings. In the Uinta Basin, the Mesaverde TPS includes the Mesaverde Group (Blackhawk Formation, Castlegate Sandstone, and Price River Formation) and the Wasatch Formation. In the Piceance Basin, the Mesaverde TPS includes the Williams Fork Formation of the Mesaverde Group and the overlying Wasatch Formation (Johnson and Roberts, 2003). The primary petroleum source rocks in the Uinta Basin are bituminous coals within the Blackhawk and Neslen Formations of the Mesaverde Group; the major source rocks in the Piceance Basin are the Cameo-Fairfield coal and carbonaceous shale deposits within the Williams Fork Formation (Johnson and Roberts, 2003). The Mesaverde TPS is mostly self-sourced with total organic carbon ranging from 10 to 70 weight percent in the Cameo-Fairfield coal (Nelson, 2003). The underlying Mancos Shale may also be an additional source of natural gas. Geochemical evidence from the Mamm Creek field in the Piceance Basin suggests that the field has more than one source of gas. The gas produced from the west side of the field is mostly intraformational coal gas, whereas the gas from the northeastern part of the field has a marine shale source, most likely the Mancos Shale (Lillis and others, 2008).

\section{Assessment Units}

Two AUs are identified in this assessment: the Uinta Mesaverde Tight Gas AU and the Piceance Mesaverde Tight Gas AU. The Uinta Mesaverde Tight Gas AU lies within the Uinta Basin part of the Uinta-Piceance Province (Johnson and Roberts, 2003) in northeast Utah and covers a maximum area of 4,088,000 acres (fig. 1). The potential AU resource boundary includes the areas where the Mesaverde Group source rock is thermally mature with vitrinite reflectance $\left(R_{\mathrm{o}}\right)$ values of 0.75 percent or greater and includes the "transitional gas" AU boundaries, as defined in Johnson and Roberts (2003). Tight gas from the Mesaverde Group and Wasatch Formation has been produced-more than 1.76 trillion cubic feet of gas (TCF) - from over 3,000 wells in the Uinta Basin, mostly from the Natural Buttes gas field in the eastern part of the basin (IHS Markit ${ }^{\text {TM }}$, 2017).

The Piceance Mesaverde Tight Gas AU lies within the Piceance Basin part of the Uinta-Piceance Province in northwest Colorado (fig. 1). Mesaverde Group and Wasatch Formation tight gas - more than 7.7 TCF - has been produced from over 12,000 wells in the Piceance Basin, mostly from the central part of the basin (IHS Markit, 2017).

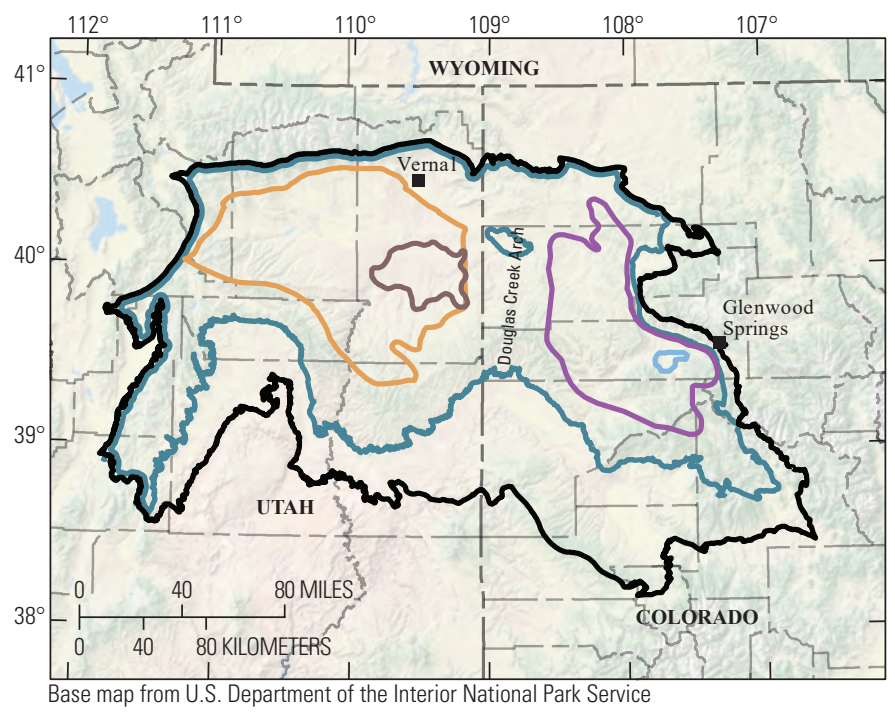

\section{EXPLANATION}

Uinta Mesaverde Tight Gas AU Piceance Mesaverde Tight Gas AU

Mesaverde Total Petroleum System Mamm Creek field

Greater Natural Buttes (GNB) field_-Includes Natural Buttes, Buck Canyon, Rock House, Island, and Oil Springs gas fields

Uinta-Piceance Province boundary

Figure 1. Location of the Uinta-Piceance Province, Utah and Colorado, with continuous assessment unit (AU) boundaries. 


\section{Undiscovered Resources Summary}

Using the USGS continuous resource methodology for assessing petroleum resources (Charpentier and Cook, 2011), we quantitatively assessed Mesaverde Group and Wasatch Formation tight-gas resources in two continuous (unconventional) AUs in the Uinta-Piceance Province (table 2). The overall total mean resources in the Uinta Mesaverde Tight Gas and the Piceance Mesaverde Tight Gas AUs are 24,033 billion cubic feet of gas (BCFG), or 24 TCF of gas, with an F95-F5 range from 6,750 to 46,469 BCFG and 96 million barrels of natural gas liquids (MMBNGL) with an F95-F5 range from 25 to 197 MMBNGL.

For the Uinta Mesaverde Tight Gas AU, the total mean resources are 19,325 BCFG, or 19.3 TCF of gas, with an F95-F5 range from 5,481 to 37,113 BCFG and 77 MMBNGL with an F95-F5 range from 20 to 158 MMBNGL. For the Piceance Mesaverde Tight Gas AU, the total mean resources are 4,708 BCFG, or 4.7 TCF of gas, with an F95-F5 range from 1,269 to 9,356 BCFG and 19 MMBNGL with an F95-F5 range from 5 to 39 MMBNGL.

\section{Mesaverde Group Tight-Gas Assessment Team}

Ronald M. Drake II, Christopher J. Schenk, Tracey J. Mercier, Phuong A. Le, Thomas M. Finn, Ronald C. Johnson, Cheryl A. Woodall, Stephanie B. Gaswirth, Kristen R. Marra, Janet K. Pitman, Heidi M. Leathers-Miller, Seth S. Haines, and Marilyn E. Tennyson

\section{For More Information}

Assessment results are also available at the USGS Energy Resources Science Center website at https://energy.usgs.gov.

Table 1. Key input data for two continuous tight-gas assessment units in the Uinta-Piceance Province, Utah and Colorado.

[AU, assessment unit; \%, percent; EUR, estimated ultimate recovery per well; BCFG, billion cubic feet of gas. The average EUR input is the minimum, median, maximum, and calculated mean. Shading indicates not applicable]

\begin{tabular}{|l|r|r|r|r|r|r|r|r|}
\hline \multirow{2}{*}{$\begin{array}{c}\text { Assessment input data- } \\
\text { Continuous AUs }\end{array}$} & \multicolumn{3}{c|}{ Uinta Mesaverde Tight Gas AU } & \multicolumn{4}{c|}{ Piceance Mesaverde Tight Gas AU } \\
\cline { 2 - 9 } & Minimum & Mode & Maximum & $\begin{array}{c}\text { Calculated } \\
\text { mean }\end{array}$ & Minimum & Mode & $\begin{array}{c}\text { Maximum } \\
\text { Calculated } \\
\text { mean }\end{array}$ \\
\hline Potential production area of AU (acres) & 1,200 & $2,050,000$ & $4,088,000$ & $2,046,400$ & 1,300 & $1,273,000$ & $1,896,000$ & $1,056,767$ \\
\hline Average drainage area of wells (acres) & 30 & 60 & 90 & 60 & 30 & 60 & 90 & 60 \\
\hline Success ratio (\%) & 50 & 70 & 90 & 70 & 50 & 70 & 90 & 70 \\
\hline Untested area in AU (\%) & 85 & 90 & 95 & 90 & 20 & 40 & 60 & 40 \\
\hline Average EUR (BCFG) & 0.2 & 0.85 & 1.7 & 0.883 & 0.2 & 0.9 & 1.9 & 0.941 \\
\hline AU probability & 1.0 & & & & 1.0 & & & \\
\hline
\end{tabular}

Table 2. Results for two continuous tight-gas assessment units in the Uinta-Piceance Province, Utah and Colorado.

[BCFG, billion cubic feet of gas; NGL, natural gas liquids; MMBNGL, million barrels of natural gas liquids. Results shown are fully risked estimates. F95 represents a 95-percent chance of at least the amount tabulated; other fractiles are defined similarly. Fractiles are additive under the assumption of perfect positive correlation. Shading indicates not applicable]

\begin{tabular}{|c|c|c|c|c|c|c|c|c|c|c|}
\hline \multirow{2}{*}{$\begin{array}{l}\text { Total petroleum system } \\
\text { and assessment units (AUs) }\end{array}$} & \multirow{2}{*}{$\begin{array}{c}\text { AU } \\
\text { probability }\end{array}$} & \multirow{2}{*}{$\begin{array}{c}\text { Accumulation } \\
\text { type }\end{array}$} & \multicolumn{4}{|c|}{ Gas (BCFG) } & \multicolumn{4}{|c|}{ NGL (MMBNGL) } \\
\hline & & & F95 & F50 & F5 & Mean & F95 & F50 & F5 & Mean \\
\hline \multicolumn{11}{|c|}{ Mesaverde Total Petroleum System } \\
\hline Uinta Mesaverde Tight Gas AU & 1.0 & Gas & 5,481 & 18,144 & 37,113 & 19,325 & 20 & 70 & 158 & 77 \\
\hline Piceance Mesaverde Tight Gas AU & 1.0 & Gas & 1,269 & 4,353 & 9,356 & 4,708 & 5 & 17 & 39 & 19 \\
\hline $\begin{array}{l}\text { Total undiscovered continuous } \\
\text { resources }\end{array}$ & & & 6,750 & 22,497 & 46,469 & 24,033 & 25 & 87 & 197 & 96 \\
\hline
\end{tabular}

\section{References Cited}

Charpentier, R.R., and Cook, T.A., 2011, USGS methodology for assessing continuous petroleum resources: U.S. Geological Survey Open-File Report 2011-1167, 73 p., accessed April 4, 2017, at https://pubs.usgs.gov/of/2011/1167.

IHS Markit ${ }^{\mathrm{TM}}, 2017$, U.S. well history and production database: Englewood, Colo., IHS Markit, accessed January 2017 at https:// www.ihsenergy.com. [Available from IHS Markit, 15 Inverness Way East, Englewood, CO 80112.]

Johnson, R.C., and Roberts, S.B., 2003, The Mesaverde Total Petroleum System, Uinta-Piceance Province, Utah and Colorado, chap. 7 of USGS Uinta-Piceance Assessment Team, Petroleum systems and geologic assessment of oil and gas in the Uinta-Piceance Province, Utah and Colorado: U.S. Geological Survey Digital Data Series DDS-69-B, ver. 1.0, 68 p., accessed January 2018 at https://pubs. usgs.gov/dds/dds-069/dds-069-b/REPORTS/Chapter_7.pdf.
Lillis, P.G., Ellis, G.S., Dempsey, M.P., and Cumella, S.P., 2008, Origin of gas in the Mamm Creek field, Piceance Basin, Colorado, in American Association of Petroleum Geologists meeting, Denver, Colo., July 9-11, 2008, Proceedings: American Association of Petroleum Geologists.

Nelson, P.H., 2003, A review of the Multiwell Experiment, Williams Fork and Iles Formations, Garfield County, Colorado, chap. 15 of USGS Uinta-Piceance Assessment Team, Petroleum systems and geologic assessment of oil and gas in the Uinta-Piceance Province, Utah and Colorado: U.S. Geological Survey Digital Data Series DDS-69-B, ver. 1.0, 28 p., accessed January 2018 at https://pubs.usgs.gov/dds/ dds-069/dds-069-b/REPORTS/Chapter_15.pdf. 